\title{
Bacterial Colonization of Ureteral Double-J Stents in Patients with Negative Urine Culture
}

\section{İrar Kültürü Negatif Olan Hastalarda Üreteral Çift-J Stentlerin Bakteriyel Kolonizasyonu}

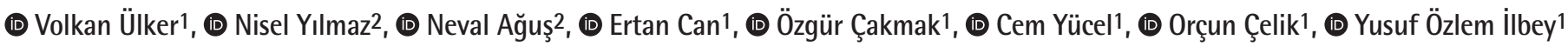 \\ ${ }^{1}$ Tepecik Training and Research Hospital, Clinic of Urology, Izmir, Turkiye \\ 2Tepecik Training and Research Hospital, Clinic of Microbiology, İmir, Turkiye
}

\section{What's known on the subject? and What does the study add?}

Urinary tract infection and sepsis are major morbidities for patients with indwelling ureteral DJ stents. The bacterial flora and predominant bacteria colonized on ureteral stents can vary in different institutions. Knowing of growing microorganism on the stent may enable us to be more effective in the postoperative antibacterial therapy in high risk patients with indwelling DJ stents.

\begin{abstract}
Objective: Ureteral double-J stents are extensively used in urology practice. We aimed to investigate the bacterial colonization rate and predominant microorganisms on ureteral double-J stents in patients with negative urine cultures in a prospective study.

Materials and Methods: A total of 35 double-J ureteral stents from 35 consecutive patients were examined. The cyctoscopically removed stents were divided into three parts as upper, middle and lower then sent for the microbiologic examination with a urine sample just taken before stent removal. The samples were inoculated on sheep blood agar and eosin-methylene blue agar culture mediums. The growth of $>1000$ colony-forming units $/ \mathrm{mL}$ was considered significant. The antimicrobial susceptibility test was performed with 10 broad spectrum antibiotics.

Results: Bacterial colonies were found in $20 \%$ of 35 ureteral stents. The most frequently isolated bacteria was Staphylococcus epidermidis, followed by Escherischia coli and Enterococcus faecalis. Bacterial colonization was revealed in all parts of the stents in 71.4\% cases. The stent indwelling time was correlated with stent culture positivity $(\mathrm{p}=0.035)$. However, no correlation was detected with gender, age and stent colonization ( $\mathrm{p} \geq 0.05)$. Conclusion: Negative urine culture result does not always rule out positive stent culture. Even not routinelly recommended, stent culture could be useful for treatment of a possible postoperative urinary tract infection and sepsis in high risk patients who undergo endourologic surgery.
\end{abstract}

Anahtar Kelimeler: Ureteral stents, Bacterial colonization, Stent culture, Urine culture

Öz

Amaç: Üreteral çift-J stentler üroloji uygulamalarında yoğun olarak kullanılmaktadır. Prospektif bir çalışma ile idrar kültürü negatif olan hastalarda üreteral çift-J stentlerdeki bakteriyel kolonizasyon ve baskın mikroorganizmaların araştırılması amaçlanmıştır.

Gereç ve Yöntem: Otuz beş ardışık hastadan çıkartılan 35 çift-J stent incelendi. Sistoskopik olarak çıkartılan stentler üst, orta ve alt olarak üç parçaya ayrılarak stent çıkartılmadan hemen önce alınan idrar örneği ile birlikte mikrobiyolojik incelemeye gönderildi. Örnekler kanlı-agar ve eozinmetilen mavisi agar besiyerlerine ekildi. Üremede >1000 koloni ünite/mL anlamlı olarak kabul edildi. Antibiyotik hassasiyet testi 10 geniş spektrumlu antibiyotik ile yapıldı.

Bulgular: Çıkartılan 35 stentin \%20'sinde bakteriyel kolonizasyon saptandı. En sık üreyen bakteri Staphilococcuss epidermidis, ardından Escherischia coli ve Enterococcus faecalis idi. \%71,4 olguda stentin tüm kısımlarında kolonizasyon saptandı. Stent kalış süresi ve stent kültürü pozitifliği arasında uyum vardı $(p=0,035)$. Ancak cinsiyet ve yaş ile stent kolonizasyonu arasında bir ilişki saptanmadı $(p \geq 0,05)$.

Sonuç: Üreteral DJ stent bulunan hastalarda idrar kültürü negatif olsa bile stent kültürü pozitif olabilmektedir. Rutin olarak önerilmemekle birlikte stent kültürü endoürolojik cerrahi yapılacak yüksek riskli hastalarda gelişebilecek postoperatif üriner sistem enfeksiyonu ve sepsisin tedavisinde faydalı olabilir.

Keywords: Üreter stenti, Bakteriyel kolonizasyon, Stent kültürü, İdrar kültürü

Correspondence: Volkan Ülker MD, Tepecik Training and Research Hospital, Clinic of Urology, İzmir, Turkiye

Phone: +90 5324324763 E-mail: ulkerv@ hotmail.com ORCID-ID: orcid.org/0000-0002-2469-8154

Received: 17.10.2018 Accepted: 07.01.2019

Cite this article as: Ülker V, Yılmaz N, Ağuş N, Can E, Çakmak Ö, Yücel C, Çelik O, İlbey YÖ. Bacterial Colonization of Ureteral Double-J Stents in Patients with Negative Urine Culture. J Urol Surg 2019;6(2):125-129.

๑Copyright 2019 by the Association of Urological Surgery / Journal of Urological Surgery published by Galenos Publishing House. 


\section{Introduction}

Ureteral double-J (DJ) stents are extensively used in the management of upper urinary tract obstruction and prevention of complications after endoscopic or open urological operations. DJ stents are also used to reduce the obstruction risk due to stone fragments after extracorporeal shock-wave lithotripsy in patients with large kidney stones (1). However, their use is associated with some morbidity, such as dysuria, hematuria, and lumbar or suprapubic pain (2). More serious complications include stent migration, fragmentation, encrustation and infection which may lead to bacteremia, pyelonephritis, renal deterioration and even death due to sepsis $(3,4,5)$. Infection and encrustation of DJ stent occur frequently because of its direct contact with urine. Furthermore, internal ureteral stents also offer an ideal surface for bacterial colonization and biofilm formation $(6,7)$. Bacterial colonization with biofilm formation on the stent plays an essential role in the pathogenesis of stentassociated infections (7). Previous studies have demonstrated a poor correlation between urine culture (UC) and stent culture (SC) results $(8,9)$. Stent-related urinary tract infections (UTIs) are often asymptomatic and resolve without any treatment, while only about $3 \%$ to $5 \%$ develop symptomatic UTI necessitating antimicrobial treatment $(10,11)$.

In this study, we aimed to investigate the incidence of bacterial colonization on DJ stents and responsible microorganisms in patients with negative UC in order to determine the clinical role of SC in clinical practice.

\section{Materials and Methods}

After obtaining approval from the institutional ethics committee, this prospective, single-arm study was conducted. DJ stents which were removed from 35 consecutive patients with negative UC between February 2018 and July 2018 were examined for the presence of pathogens. Written informed consent for the procedure and participation in the study was obtained from all patients. All of the stents were initially placed in our clinic. Only patients with unilateral indwelling standard, polyurethane DJ stents with negative UC were included. The indication for DJ stent placement was recorded. Patients with diabetes mellitus, chronic renal insufficiency or immune suppression were not included to the study. Patients with accompanying kidney stones and those who previously received antimicrobial treatment for UTI were also excluded. None of the patients have received prophylactic antibiotics before the stent removal procedure. Midstream urine samples were obtained from each patient several days before stent removal. Removal of the DJ stents was performed under local anesthesia and in aseptic conditions with 22 French (F) rigid or $15.5 \mathrm{~F}$ flexible cystoscope (Karl Storz, Tutlingen, Germany) and with grasping forceps. The removed DJ stents were divided into three parts as upper, middle and lower, then 2-3 cm pieces were taken and sent for microbiological investigation in a sterile container

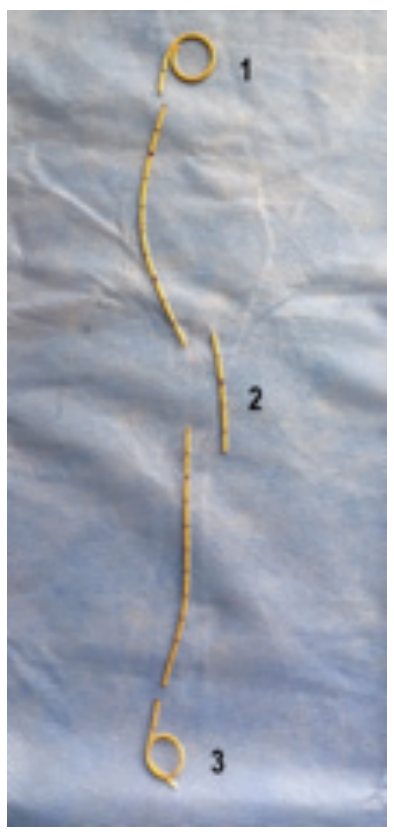

Figure 1. Diving of the double-J stent for microbiological sampling

(Figure 1).

All segments of the stent parts including inner surface, outer surface and the stent tip were washed with $1 \mathrm{~mL}$ sterile tryptic soy broth solution and then the liquid culture medium was vortexed for 1 minute to enable the detection of microorganisms attached to the outer surface of the catheter segment. Then, samples were diluted $(1 / 100)$ and inoculated on 5\% sheep blood agar and eosin methylene blue agar (BD BBL, USA). Plates were incubated for 48 hours at $37^{\circ} \mathrm{C}$. The microorganisms that grew on the agar were evaluated quantitatively (growth of $>1000$ colony-forming units $/ \mathrm{mL}$ was considered significant). Bacteria were identified by MALDI-TOF MS (Bruker, USA) and antimicrobial susceptibility testing was performed by Phoenix automated susceptibility testing system (BD, USA) using the EUCAST criteria.

\section{Statistical Analysis}

The power of the study was calculated using the $\mathrm{G}^{*}$ Power program (University of Dusseldorf, Dusseldorf, Germany) an effective size convention of 0.8 for the two-tailed t-test, with an alpha error protection of 0.05 . The Student's t-test and chisquare test were used for statistical analysis. A $p$ value of less than 0.05 was considered statistically significant. Data were analysed with SPSS version 24.0 (IBM Corp. Armonk, NY, USA). 


\section{Results}

The patients' characteristics are presented in Table 1. The majority of patients with DJ stent were male. The stent indwelling time ranged from 17 days to 72 days with a mean value of 39 days. The primary reason for DJ stent placement was ureteroscopy (URS) and laser lithotripsy in 31 (88.6\%), hydronephrosis in pregnancy in $1(2.8 \%)$, obstructive pyelonephritis in $2(5.7 \%)$ and malignancy in $1(2.8 \%)$ patient.

All urine samples taken from the urinary bladder prior to stent removal were sterile. Bacterial colonization and growth in SC was detected in 7 of 35 patients (20\%). Positive SC was more common in female patients, however, no statistically significant correlation was detected with gender $(p=0.085)$ and age $(p=0.210)$. Bacterial colonization was detected in all parts (upper, middle, lower) of the stents in 5 of $7(71.4 \%)$ patients $(p<0.05)$. In two patients, colonization was only in the middle and lower parts (28.6\%). The most frequently isolated pathogen in SC was Staphylococcus epidermidis. Bacterial colonies identified from the DJ stents are shown in the Table 2. Fungus was not detected in any patient. None of the patients with positive SC had multiple bacterial strains. The rate of bacterial colonization was $14.3 \%$ and $85.7 \%$ in patients with a stent indwelling time less than 2 weeks and more than 2 weeks, respectively. Stent indwelling time was correlated with SC positivity $(p<0.05)$. Among 7 patients with positive $\mathrm{SC}_{1} 4$ were stented after URS, 1 for hydronephrosis and 1 after open pyeloplasty operation.

Table 1. Patients' characteristics

\begin{tabular}{ll}
\hline Number of patients & $\mathrm{n}(\%) / \mathrm{SD}$ \\
Male & $35(100 \%)$ \\
Female & $21(60 \%)$ \\
\hline Mean age (years) & $14(40 \%)$ \\
\hline Colonized stent rate & $52.5 \pm 12$ \\
Male & $7(20 \%)$ \\
Female & $4(42.9 \%)$ \\
\hline Multi-resistant bacteria strains & $3(51.7 \%)$ \\
\hline Total number of colonies & $2(5.7 \%)$ \\
\hline Rate of colonies per positive stent & 11 \\
\hline Mean duration of stenting (days) & 1.21 \\
\hline
\end{tabular}

Table 2. Bacterial colonies identified from the double-J stents

\begin{tabular}{ll}
\hline Microorganism & $\mathbf{n}(\%)$ \\
\hline Sterile & $28(80)$ \\
\hline Staphylococcus epidermidis & $3(8.6)$ \\
\hline Escherichia coli & $2(5.7)$ \\
\hline Enterococcus faecalis & $2(5.7)$ \\
\hline Fungus & $0(0)$
\end{tabular}

In two of three patients, Staphylococcus epidermidis isolates were resistant to methicillin, all of them were resistant to penicillin, susceptible to erythromycin, clindamycin and ciprofloxacin. Enterococcus faecalis isolates were susceptible to ampicillin. All gram-positive isoaltes were susceptible to vancomycin, teicoplanin and linezolide. In one of two patients, Escherichia coli isolates were resistant to ampicillin and trimetoprim-sulfametaxazole, and all of them were susceptible to cefuroxime, gentamicin, amoxicillin clavulonic acid, ceftazidime, amikacin, ciprofloxacin, imipenem and meropenem. All patients with growth on SCs were treated with appropriate antibiotics according to their sensitivity tests. None of the patients had UTI symptoms during and after the treatment.

\section{Discussion}

Ureteral DJ stents have become indispensable in modern urological practise. On the other hand, bacterial adherence to urinary catheters and other prosthetic devices is a wellrecognised risk factor for UTI. As bacterial colonization of urinary stones described before, colonized ureteral DJ stents may serve as a reservoir for microorganisms giving rise to bacteriuria during stent manipulation or URS (12). Bacterial colonization of DJ stents has been shown to start within hours as stents become covered by host proteins which facilitate bacterial adhesion (13). The role of biofilm formation on stent colonization was well described. The first step involves the formation of conditioning film with extracellular molecules. Blood proteins, fibrinogen and inflammatory peptides appear to be involved in conditioning film formation. In the second step, the conditioning film proteins with other proteins, such as collagen, fibrinogen and albumin, allow attachment of microorganisms. Finally, bacterial growth under conditional film allows biofilm formation $(11,14)$. A recent study demonstrated that minutes after insertion of the stent, depositions of the host urinary components formed a conditioning film on the stent (15). Urinary $\mathrm{pH}$ also plays an important role. The enzyme urease produced by bacteria such as Proteus mirabilis and Pseudomonas species splits urea to ammonia and increased urinary $\mathrm{pH}$ results in precipitation of magnesium ammonium phosphate (struvite) and calcium phosphate crystals. These crystals lead to incrustation and mineralization of the biofilm layer on the stent. Bacterial fimbriae and polymeric substances produced by the bacteria are key virulence factors. In this biofilm environment, microorganisms appear to be more resistant to antimicrobial agents.

Bacterial colonization of DJ stents has an important role in the pathogenesis of stent-associated UTI, however, the relationship between DJ stents and the development of UTI is not very clear. Stent colonization does not always lead to bacteriuria. 
Therefore, negative UC does not rule out a colonized stent. Kehinde et al. (12) reported that about $17 \%$ of patients with indwelled DJ stent developed significant bacteriuria while $42 \%$ of patients had their stents colonized. They showed that in about $60 \%$ of their patients with colonized DJ stents, the UC was sterile. Similarly, Lifschitz et al. (8) found bacteriuria in $15 \%$ of their patients and $45 \%$ of patients to have colonized DJ stents. However, Reid et al. (11), in an earlier study, reported a stent colonization rate of $90 \%$ in their series of 30 patients. Our stent colonization rate was $20 \%$. However, it should be kept in mind that our study included only patients with negative UC.

Dwelling time is considered a crucial factor for bacterial colonization of DJ stents. In majority of the studies, stent dwelling times were correlated with colonization rates $(12,16)$. The longer the stent was indwelling, the higher number of stents colonized. Paick et al. (17) reported that adhesion process started 2 weeks after the stent insertion. Similarly, Shabenaa et al. (18) found that there was no bacterial colonization in the first two weeks of stent placement. In this study, stent colonization rates of $27.8 \%, 46.2 \%, 66.7 \%$ and $87.5 \%$ were detected in $15-$ 30 days, 30-60 days, 60-90 days and 90-120 days of indwelling times, respectively. In a prospective study by Farsi et al. (6), SCs were obtained from 266 patients for a duration of 2 weeks to 27 months and a direct association was found between the indwelling time, bacteriuria and stent colonization. On the other hand, Klis at al. (9) observed no relationship between the dwelling time and stent colonization. Our results are consistent with the findings of previous studies showing higher risk of colonization with increased stent indwelling time.

Several microorganisms were identified from the stents. In many studies, Eschericha coli and Enterococci spp were found to be predominant $(6,12,19)$. In our study, Staphylococcus epidermidis MR was found as predominant bacteria in SCs. Similarly, two recent publications described gram-positive pathogens, particularly Staphylococcus as predominant bacterium $(20,21)$. Predominance of gram-positive bacteria in SCs might be explained by urethral catheterisation after DJ stenting. In our study, 6 of 7 (85.7\%) patients with positive SC had a history of postoperative urethral catheterisation up to 24 hours. Farsi et al. (6) indicated that Pseudomonas aeroginosa was most frequently isolated from both stent and urine. It seems isolated predominant microorganisms can be variable in different institutions and different countries.

It has been showed that bacteria obtained from indwelling DJ stents were more resistant to antibiotics than those isolated from urine before stent insertion. This situation was explained by the expression of biofilm-specific genes (12). During stent manipulations or ureteroscopic procedures, microorganisms may be shed into the urine and may lead to sepsis if SC is positive. Therefore, endoscopic procedures after stent removal increase the risk of infectious complications, even if preoperative UC is negative. Nevo et al. (22) found SC positivity in $20.4 \%$ of their pre-stented patients prior to ureteroscopic surgery and concluded that positive SC was associated with a higher risk of post-URS sepsis in females and patient with comorbidity. They reported that positive SC was an independent predictor of post-URS sepsis. Again, it has been reported that a dwelling time more than 30 days prior to URS was associated with five-fold increase in the risk of sepsis compared to dwelling times less than 30 days (14). Diabetes mellitus, chronic renal insufficiency and immunosuppression have also been shown to be risk factors associated with bacteriuria and stent colonization $(12,19)$. Kehinde et al. $(12)$ showed that these comorbities were associated with significantly higher rates of bacteriuria and stent colonization. In several studies, sex and age were reported to be significant predisposing factors for stent colonization $(12,22)$. On the contrary, Lifshitz et al. (8) stated that age and sex had no influence on the incidence of bacteriuria and stent colonization. The difference in sex might be explained by the anatomic closeness of the orifices in the female genital tract. Although we did not find any relationship of SC positivity with gender and age, our patient number is limited to make a comment.

\section{Study Limitations}

The main limitation of our study is the small number of patients. Secondly, we did not investigate the relationship of positive colonization with urethral catheterization. Since the predominant colonized bacterium was Staphylococcus sp. in our study, its relationship with urethral contamination needs to be investigated in future studies.

\section{Conclusion}

The majority of colonized stents are asymptomatic, therefore, routine SC cannot be clearly recommended. However, SC could be recommended in pre-stented high-risk patients having uncontrolled diabetes, immune suppression or chronic diseases with a risk of urosepsis after ureteroscopic intervention. SC can be useful in decision making regarding the optimal antibiotherapy in these patients with postoperative UTI. Additionally, the knowledge of the bacteriologic flora on ureteric DJ stents of a specific institution and country will be helpful for an evidencebased prophylaxis and treatment in high-risk patients. As a conclusion, culturing of the DJ stents can be useful in selected patients.

\section{Ethics}

Ethics Committee Approval: This study was approved by the Health Sciences University, Tepecik Training and Research Hospital Ethics Committee (approval number: 2018/4-3). 
Informed Consent: Consent form was filled out by all study participants.

Peer-review: Externally peer-reviewed.

\section{Authorship Contributions}

Surgical and Medical Practices: V.Ü., E.C., Ö.Ç., N.A, N.Y., Concept: V.Ü, E.C., N.Y., Design: V.Ü., Data Collection or Processing: N.A., V.Ü., Analysis or Interpretation: N.Y., Y.Ö.İ., Literature Search: C.Y., O.Ç., Writing: V.Ü.

Conflict of Interest: No conflict of interest was declared by the authors.

Financial Disclosure: The authors declared that this study received no financial support.

\section{References}

1. Bierkens AF, Hendrikx AJ, Lemmens WA, Debruyne FM. Extracorporeal shock wave lithotripsy for large renal calculi: the role of ureteral stents. A randomized trial. J Urol 1991;145:699-702.

2. Joshi HB, Stainthorpe A, Keeley FX, MacDonagh R, Timoney AG. Indwelling ureteral stents: evaluation of quality of life to aid outcome analysis. $J$ Endourol 2001;15:151-154.

3. Damiano R, Oliva A, Esposito C, De Sio M, Autorino R, D'Armiento M. Early and late complications of double pigtail ureteral stent. Urol Int 2002;69:136-140.

4. Aron M, Ansari MS, Singh I, Gautam G, Kolla SB, Seth A, Gupta NP. Forgotten ureteral stentscausing renal failure: multimodal endourologic treatment. $J$ Endourol 2006;20:423-428.

5. Singh V, Sirinivastava A, Kapoor R, Kumar A. Can the complicated forgotten indwelling ureteric stents be lethal? Int Urol Nephrol 2005;37:541-546.

6. Farsi HM, Mosli HA, Al-Zemaity MF, Bahnassy AA, Alvarez M. Bacteriuria and colonization of double-pigtail ureteral stents: long-term experience with 237 patients. J Endourol 1995;9:469-472.

7. Riedl $C R$, Plas $E$, Hübner $W A$, Zimmerl $H$, Ulrich $W$, Pflüger $H$. Bacterial colonization of ureteral stents. Eur Urol 1999;36:53-59.

8. Lifshitz DA, Winkler HZ, Gross M, Sulkes J, Baniel J, Livne PM. Predictive value of urinary cultures in assesment of microbial colonization of ureteral stents. J Endourol 1999;13:735-738.
9. Klis R, Korczak-Kozakiewicz E, Denys A, Sosnowski M, Rozanski W. Relationship between urinary tract infection and self-retaining Double- $J$ catheter colonization. J Endourol 2009;23:1015-1019.

10. Richter S, Ringel A, Shalev M, Nissenkorn I. The indwelling ureteric stent: a "friendly" procedure with unfriendly high morbidity. BJU Int 2000;85:408411.

11. Reid G, Denstedt JD, Kang YS, Lam D, Nause C. Microbial adhesion and biofilm formation on ureteral stents in vitro and in vivo. J Urol 1992;148:15921594.

12. Kehinde EO, Rotimi VO, Al-Hunayan A, Abdul-Halim H, Boland F, Al-Awadi K. Bacteriology of urinary tract infection associated with indwelling $J$ ureteral stents. J Endourol 2004;18: 891-896.

13. Zumstein V, Betschard P, Albrich WC, Buhmann MT, ren Q, Schmit HP, Abt D. Biofilm formation on ureteral stents-incidence, clinical impact, and prevention. Swiss Med Wkly 2017;3:w14408.

14. Nevo A, Mano R, Baniel J, Lifshitz DA. Ureteric stent dwelling time: a risk factor for post-ureteroscopy sepsis. BJU Int 2017;120:117-122.

15. Gabi M, HefermehI L, Lukic D, zahn R, Vörös J, Eberli D. Electrical microcurrent to prevent conditioning film and bacterial adhesion to urological stents. Urol Res 2011;39:81-88.

16. Lojanapiwat B. Colonization of internal ureteral stent and bacteriuria World J Urol 2006;24:681-683.

17. Paick SH, Park HK, Oh SJ, Kim HH. Characteristics of bacterial colonization and urinary tract infection after indwelling of double-j ureteral stent. Urology 2003;62:214-217.

18. Shabenaa KS, Bhargava $R$, Manzoor MAP, Mujeeburahiman $M$. Characteristics of bacterial colonization after indwelling double-J ureteral stents for different time duration. Urol Ann 2018;10:71-75.

19. Akay AF, Aflay U, Gedik A, Şahin H, Bircan MK. Risk factors for lower urinary tract infection and bacterial stent colonization in patients with a double j ureteral stent. Int Urol nephrol 2007;39:95-98.

20. Kozyrakis D, Perikleous S, Chatzistamou SE, Kateris D, Soukias D, Karatzas A, Dimitriadis I. Is there a role for double J stent culture in contemporary urology? Urol Int 2018;100:203-208.

21. Aydin HR, Irkilata $H$, Aydin M, Gorgun $S$, Demirel HC, Adanur $S$, Keles $M$, Atilla A, Atilla MK. Incidence of bacterial colonisation after indwelling og double-J ureteral stent. Arch Ital Urol Androl 2016;87:291-294.

22. Nevo A, Mano R, Schreter $E_{1}$ Lifshitz DA. Clinical implications of stent culture in patients with indwelling ureteral stents prior to ureteroscopy. J Urol 2017;198:116-121. 